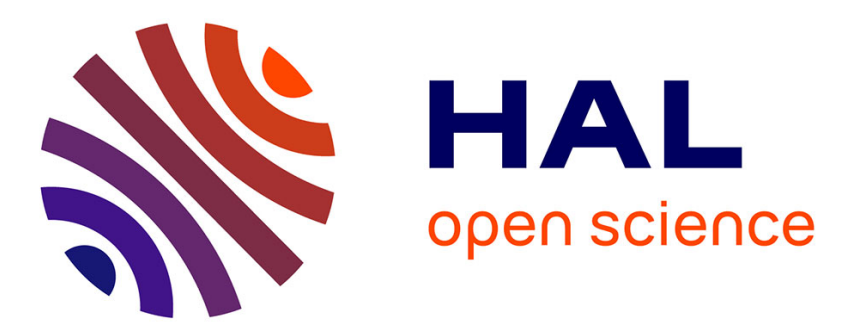

\title{
PULSED MULTICHANNEL RAMAN SPECTROMETRY OF TRANSIENT SPECIES : STRUCTURAL STUDY OF THE TRIPLET STATE OF DIAMINES
}

\author{
G. Buntinx, M. Bridoux, A. Deffontaine, O. Poizat
}

\section{To cite this version:}

G. Buntinx, M. Bridoux, A. Deffontaine, O. Poizat. PULSED MULTICHANNEL RAMAN SPECTROMETRY OF TRANSIENT SPECIES : STRUCTURAL STUDY OF THE TRIPLET STATE OF DIAMINES. Journal de Physique Colloques, 1987, 48 (C7), pp.C7-741-C7-742. 10.1051/jphyscol:19877182 . jpa-00227007

\section{HAL Id: jpa-00227007 https://hal.science/jpa-00227007}

Submitted on 1 Jan 1987

HAL is a multi-disciplinary open access archive for the deposit and dissemination of scientific research documents, whether they are published or not. The documents may come from teaching and research institutions in France or abroad, or from public or private research centers.
L'archive ouverte pluridisciplinaire HAL, est destinée au dépôt et à la diffusion de documents scientifiques de niveau recherche, publiés ou non, émanant des établissements d'enseignement et de recherche français ou étrangers, des laboratoires publics ou privés. 


\title{
PULSED MULTICHANNEL RAMAN SPECTROMETRY OF TRANSIENT SPECIES : STRUCTURAL STUDY OF THE TRIPLET STATE OF DIAMINES
}

\author{
G. BUNTINX, M. BRIDOUX, A. DEFFONTAINE and O. POIZAT \\ LASIR, CNRS LP. 2641, Université des Siences et Techniques de \\ Lille-Flandres-Artois, Batiment C.5, F-59655 Villeneuve-d'Ascq \\ Cedex, France \\ "LASIR, CNRS LP 2631, 2, Rue Henri Dunant, F-94320 Thiais, \\ France
}

Resonance Raman spectroscopy with pulsed Laser excitation and multichannel optical detection is a very sensitive tool to detect and study transient species in solution. We have used the pump-then-probe technique to analyse by time resolved resonance Raman spectroscopy the first excited triplet state of various derivatives of the $N, N, N^{\prime}, N^{\prime}$ tetramethyl-p-phenylenediamine (TMPD) - $\left.\left(\mathrm{CH}_{3}\right)_{2} \mathrm{~N}-\mathrm{C}_{6} \mathrm{H}_{4}-\mathrm{N}\left(\mathrm{CH}_{3}\right)_{2}, \quad\left(\mathrm{CD}_{3}\right)_{2} \mathrm{~N}-\mathrm{C}_{6} \mathrm{H}_{4}-\mathrm{N}(\mathrm{CD})_{3}\right)_{2}$,

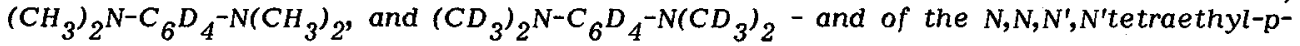
phenylenediamine (TEPD) - $\left(\mathrm{C}_{2} \mathrm{H}_{5}\right)_{2} \mathrm{~N}-\mathrm{C}_{6} \mathrm{H}_{4}-\mathrm{N}\left(\mathrm{C}_{2} \mathrm{H}_{5}\right)_{2}$ and $\left(\mathrm{C}_{2} \mathrm{H}_{5}\right)_{2} \mathrm{~N}-\mathrm{C}_{6} \mathrm{D}_{4}-\mathrm{N}\left(\mathrm{C}_{2} \mathrm{H}_{5}\right)$. All compounds have been synthetized in the laboratory. The lowest-energy triplet state is populated via intersystem crossing from the first singlet excited state after laser excitation.

We use a $10 \mathrm{~Hz}$ Q-switched YAG laser (Quantel Y G 581 C). The $1.06 \mu \mathrm{m}$ pulses are frequency doubled $(532 \mathrm{~nm})$ and tripled $(355 \mathrm{~nm})$. The second harmonic pumps a dye laser (Quantel TDL 50) whose output can be tuned between 400 and $750 \mathrm{~nm}$. The pulses widths are $12 \mathrm{~ns}$ for the pump $(355 \mathrm{~nm})$ and $8 \mathrm{~ns}$ for the probe $(610 \mathrm{~nm}$ in this experiment). The pump and probe beams are temporally delayed (50ns) by an optical delay line and spatially recombined inside the sample cell. The scattered light is collected at $90^{\circ}$ and analysed by a Dilor Raman multichannel spectrometer (OMARS 89). The spectral resolution is $3.4 \mathrm{~cm}^{-1}$ at $610 \mathrm{~nm}$ for an analysed field of $240 \mathrm{~cm}^{-1}$.

The multichanel detector is a gated intensified photodiode array. The gate pulses (20ns) are synchronized with the laser shots in order to discriminate between the Raman scattered photons and spurious photons. The multichannel detector is interfaced with an IBM PC AT computer. Signal averaging over 1000 laser shots is generally required to increase the signal to noise ratio.

The sample cell is a $10 \mathrm{~mm}$ long quartz cell. Compounds are dissolved in cyclohexane or deuterated cyclohexane. Deaerated samples are prepared by passing nitrogen through the sample for approximately $15 \mathrm{~min}$. The optimal TMPD and TEPD concentration is found to be about $10^{-2} \mathrm{M}$. 


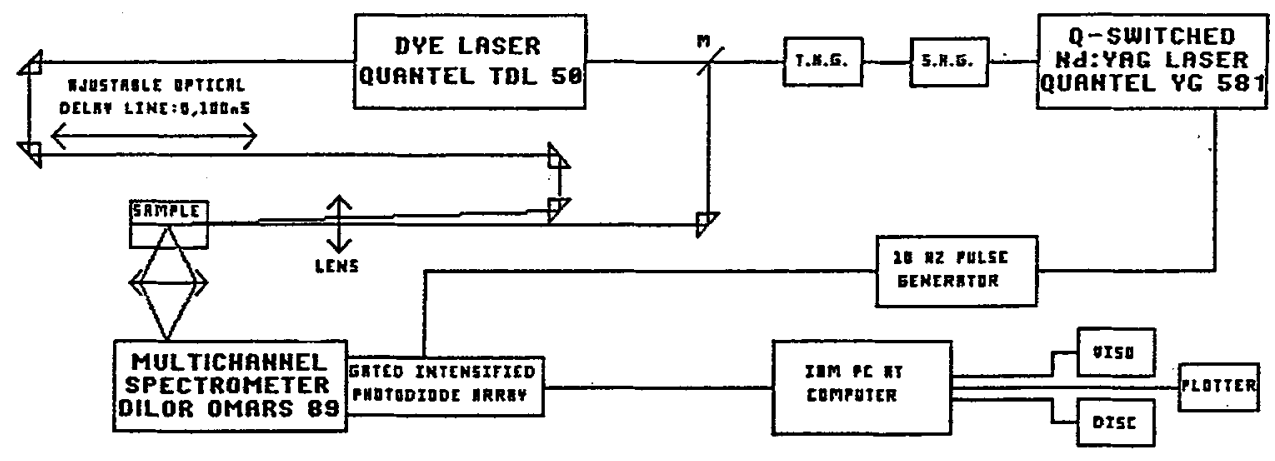

Block diagram of the Raman pump / probe experimental set-up

Since the triplet Raman spectra are obtained in resonance with the $T_{n}+T_{1}$ absorption, only bands due to the $T_{1}$ chromophore are expected to be observed. Most of the TMPD and TEPD triplet Raman signal can be straightforwardly assigned to vibrations of the $\mathrm{N}-(\text { alkyl })_{2}$ groups, which are thus strongly involved in the $T_{1}$ chromophore. The intense Raman band around $1500 \mathrm{~cm}^{-1}$ clearly implicates a significant contribution from the $v(N$-ring) vibration, indicating an increase of the $\pi$-character of the $N$-ring bonds in the triplet state. A structural model, with quinoidal ring conformation, and possible out-of-plane distortions of the amino groups is proposed. The main $T_{1}$ chromophore is probably localized on the electrons system of the N-ring bonds. However, the resonance Raman activity of several modes of the $\mathrm{N}-(\text { alkyl })_{2}$ groups indicates that strong couplings between these modes and the $\nu$ (N-ring) vibration take place in the triplet state. 